REGULAR ARTICLE

\title{
UTILIZATION OF CONVENTIONAL AND NON-CONVENTIONAL ORGANIC SOURCES AND INDUSTRIAL BY-PRODUCTS FOR YIELD MAXIMIZATION OF BRINJAL IN COASTAL SOIL
}

\section{VENKATAKRISHNAN}

Department of Soil Science and Agricultural Chemistry, Annamalai University, Annamalainagar 608002, Tamil Nadu, India

\begin{abstract}
This study was conducted to evaluate the response of brinjal (Solanum melongena L.) with conventional, non-conventional organic source, industrial by-products combined with inorganic fertilizers. The treatments imposed were $\mathrm{T}_{1}-\mathrm{Control}$ (100\% RDF), $\mathrm{T}_{2}-100 \% \mathrm{RDF}+$ Municipal Solid Waste Compost @ $5 \mathrm{t} \mathrm{ha}^{-1}, \mathrm{~T}_{3}-100 \% \mathrm{RDF}+$ Municipal Solid Waste Compost @ 10 $\mathrm{t}$ ha ${ }^{-1}, \mathrm{~T}_{4}-100 \%$ RDF+Vermicompost @ $2.5 \mathrm{t} \mathrm{ha}^{-1}, \mathrm{~T}_{5}-100 \%$ RDF+Vermicompost @ $5 \mathrm{t} \mathrm{ha}^{-1}, \mathrm{~T}_{6}-100 \%$ RDF+Rice Husk Ash @ 5 t ha ${ }^{-1}, \mathrm{~T}_{7}-100 \%$ RDF+Rice Husk Ash @ 10 t ha $^{-1}, \mathrm{~T}_{8}-100 \%$ RDF+Lignite Fly Ash @ $5 \mathrm{t} \mathrm{ha}^{-1}, \mathrm{~T}_{9}-100 \%$ RDF+Lignite Fly Ash @ 10 t ha ${ }^{-1}$. There were nine treatments combinations replicated thrice in CRD. The soil was sandy in texture with available nitrogen, phosphorus and potassium of $257,10.2$ and $117 \mathrm{~kg} \mathrm{ha}^{-1}$ respectively which fell in fertility status of low. The soil classified taxonomically as Typic Udisamments. The results showed that application of $100 \% \mathrm{RDF}+$ Vermicompost @ $5 \mathrm{t} \mathrm{ha}^{-1}\left(\mathrm{~T}_{5}\right)$ significantly increased yield attributes viz., fruit length $(16.6 \mathrm{~cm})$, fruit girth $(15.2 \mathrm{~cm})$, no. of fruits plant ${ }^{-1}(20.67)$, fruit weight $(45.2 \mathrm{~g})$ and fruit yield plant ${ }^{-1}$ (934.2 $\left.\mathrm{g} \mathrm{plant}^{-1}\right)$. This treatment registered maximum quality attributes like ascorbic acid content $\left(4.5 \mathrm{mg}^{100} \mathrm{~g}^{-1}\right)$, crude protein $(4.81 \%)$, dry matter of fruit $\left(70.2 \mathrm{~g} \mathrm{plant}^{-1}\right)$ and dry matter of plant $\left(81.3 \mathrm{~g} \mathrm{plant}^{-1}\right)$. The post harvest soil available $\mathrm{N}$ (148 mgkg-1) and P (7.15 $\left.\mathrm{mgkg}^{-1}\right)$ status was higher due to application of 100\% RDF with Vermicompost @ $5 \mathrm{t}^{-1}\left(\mathrm{~T}_{5}\right)$. The post harvest available K (75.58 mgkg-1) status recorded higher in the treatment $\mathrm{T}_{9}$ which received $100 \% \mathrm{RDF}$ with Lignite Fly Ash @10 tha-1 $\left(\mathrm{T}_{9}\right)$.
\end{abstract}

\section{INTRODUCTION}

Brinjal (Solanum melongena L.) is one among the important vegetable crops widely cultivated in India. It can be grown in almost all parts of India except higher altitudes, al the year round. In India, brinjal cultivation is taken up in an area of 0.72 million hectares with an annual production of 13.44 million tonnes with its productivity of 18.6 tonnes per hectare [1]. There are some previous studies to improve the cultivation and production of brinjal, but the research in organic production is comparatively less [2]. With this preview the investigation was undertaken to study the influence of conventional and non-conventional organic sources and inorganic fertilizers on growth, yield and quality parameters of pot experiment.

\section{MATERIALS AND METHODS}

The pot experiment was conducted in Department of Soil Science and Agricultural Chemistry, Annamalai University to evaluate the response of municipal solid waste compost, vermicompost, rice husk ash and lignite fly ash in brinjal. The treatment details of the pot culture experiment were imposed.

$\mathrm{T}_{1}$-Control-100\% RDF, $\mathrm{T}_{2}-100 \% \mathrm{RDF}+$ Municipal solid waste compost @ $5 \mathrm{t} \mathrm{ha}^{-1}, \mathrm{~T}_{3}-100 \% \mathrm{RDF}+$ Municipal solid waste compost @ 10 t ha-1, $\mathrm{T}_{4}-100 \% \mathrm{RDF}+$ Vermicompost @ $2.5 \mathrm{tha}^{-1}, \mathrm{~T}_{5}-100 \% \mathrm{RDF}+$ Vermicompost @ $5 \mathrm{t} \mathrm{ha}^{-1}, \mathrm{~T}_{6}-$ 100\% RDF+Rice husk ash @ $5 \mathrm{t} \mathrm{ha}^{-1}, \mathrm{~T}_{7}-100 \% \mathrm{RDF}+$ Rice husk ash @ $10 \mathrm{t} \mathrm{ha}^{-1}, \mathrm{~T}_{8}-100 \%$ RDF+Lignite fly ash @ $5 \mathrm{t}$ $\mathrm{ha}^{-1}$ and $\mathrm{T}_{9}-100 \%$ RDF+Lignite fly ash @ 10 t ha ${ }^{-1}$. The design followed was completely randomized block design. The Physico chemical properties viz., pH,EC,organic carbon, available NPK, were recorded for initial soil sample analysis. Brinjal yield attributes,fruit yield plant-1 and stover yield plant-1 were recorded. The post harvest analysis of available NPK were estimated by using standard procedures [3].

\section{RESULTS AND DISCUSSION}

The composite soil at $0-15 \mathrm{~cm}$ collected from Killai and were tested for the various physico-chemical properties. The textural composition of soil was sandy. The experimental soil of Killai comes under the taxonomical classification. Typic Udisamments. The cation exchange capacity $\left(8.2\left[\mathrm{cmol}\left(\mathrm{p}^{+}\right) \mathrm{kg}^{-1}\right)\right.$, soil pH (7.83 with EC of 0.22 $\left.\mathrm{dS} \mathrm{m} \mathrm{m}^{-1}\right)$, organic carbon $\left(2.8 \mathrm{~g} \mathrm{~kg}^{-1}\right)$, nitrogen, phosphorus and potassium in soil were 257, 10.2 and $117 \mathrm{~kg} \mathrm{ha}^{-1}$ respectively.

The present study revealed that application of $100 \%$

\section{Received 21 March 2018; Accepted 27 April 2018 \\ *Corresponding Author \\ D. Venkatakrishnan}

Department of Soil Science and Agricultural Chemistry, Annamalai University, Annamalainagar 608002, Tamil Nadu, India

Email: mahemasree@yahoo.co.in

()This article is open access and licensed under the terms of the Creative Commons Attribution License (http://creativecommons.org/licenses/by/4.o/) which permits unrestricted, use, distribution and reproduction in any medium, or format for any purpose, even commercially provided the work is properly cited. Attribution - You must give appropriate credit, provide a link to the license, and indicate if changes were made. 
RDF+Vermicompost @ $5 \mathrm{t} \mathrm{ha}^{-1}\left(\mathrm{~T}_{5}\right)$ registered highest yield attributes like mean fruit length $(16.6 \mathrm{~cm})$, fruit girth $(15.2$ $\mathrm{cm})$, no. of fruits per plant (20.6), fruit weight (45.2 g) and fruit yield per plant (934.2 $\mathrm{g} \mathrm{plant}^{-1}$ ) (table 1). The combined application of conventional, non-conventional organic sources, industrial by-products and fertilizers provide optimum nutrient status to the plants [4].

The pot culture experiment observed that application of 100\% RDF+Vermicompost @ $5 \mathrm{t} \mathrm{ha}^{-1}\left(\mathrm{~T}_{5}\right)$ registered highest fruit yield (415.3 g plant $^{-1}$ ) and stover yield (230.0 $\mathrm{g}$ plant $^{-1}$ ) (table 1). The increased fruit weight and fruit yield per plant might be due to the optimum growing environment, better utilization of inorganic nitrogen due to presence of vermicompost, municipal soil waste compost thereby enhancing synthesis of growth hormones viz., IAA, cytokinin, auxins etc. Similar observations have been made by Abdel-Mouty et al. [5].

The highest vitamin $\mathrm{C}$ content (4.5 $\mathrm{mg} \mathrm{oog}^{-1}$ ) and crude protein content $(4.81 \%)$ were recorded in the treatment receiving $100 \% \mathrm{RDF}+$ Vermicompost @ $5_{\text {tha }^{-1}(\mathrm{~T} 5)}$ (table 2). It can be inferred that organic manures enhanced their efficiency of growth promoting substances which accelerate physiological processes for vitamin $\mathrm{C}$ content. The application of vermicompost may be the reason of increased uptake [6].
The results of pot experiment indicated that application of $100 \%$ RDF+Vermicompost @ $5 \mathrm{t} \mathrm{ha}^{-1}\left(\mathrm{~T}_{5}\right)$ rated best in recoding the highest $\mathrm{N}$ availability in soil (table 2). It registered $148 \mathrm{mg} \mathrm{kg}^{-1}$ in the post harvest soil analysis of pot experiment. It might be attributed to the release of nitrogen to the soil because of congenial environment for soil organism involved in nitrogen transformation. Balaji [7] found that application of organics increased the nitrogen content in soil.

. Among treatments addition of $100 \% \mathrm{RDF}+$ Vermicompost @ $5 \mathrm{t} \mathrm{ha}^{-1}\left(\mathrm{~T}_{5}\right)$ significantly increased the Olsen-P in soil. The result of pot experiment also indicated the usefulness of this treatment in increasing the $\mathrm{P}$ availability to $7.15 \mathrm{mg}$ $\mathrm{kg}^{-1}$ (table 2). Manures are always being much more effective than soil inorganic $P$ fertilizers in increasing the available $\mathrm{P}$ in the soil [8].

Among treatments, application of $100 \%$ RDF+Lignite Fly Ash @ $10 \mathrm{t} \mathrm{ha}^{-1}\left(\mathrm{~T}_{9}\right)$ recorded the highest K concentration (table 2). This treatment recorded $75.58 \mathrm{mg} \mathrm{kg}^{-1}$ at the harvest stage. It might be due to the higher $\mathrm{K}_{2} \mathrm{O}$ content of fly ash (8.3\%) compared to other organic sources. Application of both organic and inorganic fertilizers brought changes in soil properties and also influenced the availability of native nutrients. This is in line with previous findings $[9,10]$.

Table 1: Effect of conventional, non-conventional organic sources and industrial by-products on brinjal mean fruit length, mean fruit girth, no. of fruits plant $^{-1}$, mean fruit weight, fruit yield, stover yield, ascorbic acid and crude protein

\begin{tabular}{|c|c|c|c|c|c|c|c|c|}
\hline Treatments & $\begin{array}{l}\text { Mean } \\
\text { fruit } \\
\text { length } \\
\text { (cm) }\end{array}$ & $\begin{array}{l}\text { Mean } \\
\text { fruit } \\
\text { girth } \\
\text { (cm) }\end{array}$ & $\begin{array}{l}\text { No. of } \\
\text { fruits } \\
\text { plant }\end{array}$ & $\begin{array}{l}\text { Mean } \\
\text { fruit } \\
\text { weight } \\
\text { (g) }\end{array}$ & $\begin{array}{l}\text { Fruit } \\
\text { yield } \\
\left.\text { (g plant }{ }^{-1}\right)\end{array}$ & $\begin{array}{l}\text { Stover } \\
\text { yield (g } \\
\left.\text { plant }^{-1}\right)\end{array}$ & $\begin{array}{l}\text { Ascorbic } \\
\text { acid } \\
\left(\mathrm{mg} 100 \mathrm{~g}^{-1}\right)\end{array}$ & $\begin{array}{l}\text { Crude } \\
\text { protein } \\
(\%)\end{array}$ \\
\hline $\mathrm{T}_{1}$ & 13.6 & 12.6 & 19.1 & 42.1 & $815 \cdot 3$ & 230.0 & 3.94 & 3.96 \\
\hline $\mathrm{T}_{2}$ & 14.6 & $14 \cdot 3$ & 20.0 & 44.2 & 884.6 & 330.2 & $4 \cdot 312$ & 4.57 \\
\hline $\mathrm{T}_{3}$ & 15.0 & 14.6 & 20.3 & 44.7 & 908.6 & 385.3 & $4 \cdot 38$ & 4.65 \\
\hline $\mathrm{T}_{4}$ & 16.3 & 15.0 & 20.3 & 45.0 & 916.3 & 403.7 & 4.43 & 4.78 \\
\hline $\mathrm{T}_{5}$ & 16.6 & 15.2 & 20.6 & 45.2 & 934.2 & 417.5 & 4.50 & 4.81 \\
\hline $\mathrm{T}_{6}$ & $14 \cdot 3$ & 13.7 & $19 \cdot 3$ & 43.2 & 835.6 & 301.7 & 4.20 & $4 \cdot 33$ \\
\hline $\mathrm{T}_{7}$ & 14.3 & 13.9 & 19.6 & 43.8 & 862.3 & 330.5 & 4.23 & 4.48 \\
\hline $\mathrm{T}_{8}$ & 13.6 & 13.1 & 19.3 & 42.7 & 826.6 & 250.8 & 3.98 & 4.06 \\
\hline $\mathrm{T}_{9}$ & 14.0 & 13.7 & 19.3 & 43.0 & 831.3 & 280.5 & 4.13 & 4.21 \\
\hline Mean & 14.7 & 14.0 & 19.7 & 43.7 & 868.3 & 328.9 & 4.22 & $4 \cdot 32$ \\
\hline S. Ed. & 0.3 & 0.4 & 0.47 & 0.78 & 2.3 & 8.2 & 0.08 & 0.09 \\
\hline $\mathrm{CD}(\mathrm{p}=0.05)$ & 0.6 & 0.8 & 0.99 & 1.64 & 4.9 & 17.3 & 0.17 & 0.18 \\
\hline
\end{tabular}

Table 2: Effect of conventional, non-conventional organic sources and industrial by-products on available NPK contents of soil

\begin{tabular}{|c|c|c|c|}
\hline Treatments & $\begin{array}{l}\mathrm{N} \\
\left(\mathrm{mg} \mathrm{kg} \mathrm{kg}^{-1}\right)\end{array}$ & $\begin{array}{l}P \\
\left(\mathrm{mg} \mathrm{kg}^{-1}\right)\end{array}$ & $\begin{array}{l}\text { K } \\
(\mathrm{mg} \mathrm{kg-1})\end{array}$ \\
\hline $\mathrm{T}_{1}$ & 131.0 & 5.20 & 60.42 \\
\hline $\mathrm{T}_{2}$ & 134.5 & 6.38 & 70.04 \\
\hline $\mathrm{T}_{3}$ & $145 \cdot 5$ & 6.50 & 72.98 \\
\hline $\mathrm{T}_{4}$ & 146.0 & 6.73 & 73.14 \\
\hline $\mathrm{T}_{5}$ & 148.0 & 7.15 & 74.13 \\
\hline $\mathrm{T}_{6}$ & 131.5 & 5.63 & 67.92 \\
\hline $\mathrm{T}_{7}$ & 132.0 & 5.68 & 68.16 \\
\hline $\mathrm{T}_{8}$ & 130.5 & 5.28 & $75 \cdot 58$ \\
\hline $\mathrm{T}_{9}$ & 132.0 & $5 \cdot 38$ & 77.48 \\
\hline Mean & 136.7 & 5.94 & 71.09 \\
\hline S. Ed. & 3.1 & 0.1 & 1.4 \\
\hline $\mathrm{CD}(\mathrm{p}=0.05)$ & 6.4 & 0.2 & 2.9 \\
\hline
\end{tabular}




\section{REFERENCES}

1. Department of Agriculture and Co-operation, 2013. Agricultural statistics at a glance 2013;128-185.

2. Chaudhary AS, Uniyal SP, Pandey P. Evaluation of new genotypes of brinjal (Solacanum melongena L.) under tarai condition of Uttarakhand. Journal of Applied and Natural Science. 2017;9:1840-3.

3. Jackson ML. Soil Chemical Analysis. New Jersy Prentice. Hall. Inc. pp. 1973;448.

4. Ullah MS, Islam MS, Islam MA, Haque T. Effects of organic manures and chemical fertilizers on the yield of brinjal and soil properties. Journal of the Bangladesh Agricultural University. 2008;6:271-6.

5. Abdel-Mouty MM, Mahmoud AR, El-Desuki M, Rizk FA. Yield and fruit quality of eggplant as affected by organic and mineral fertilizers application. Research Journal of Agriculture and Biological Sciences. 2011;7:196-202.
6. Tejada M, González JL. Application of two vermicompost on a rice crop: effects on soil biological properties and rice quality and yield. Agronomy journal. 2009;101:336-44.

7. Balaji SK. Effect of vermicompost on growth and flower yield of china aster (Callistephus chinensis). $\mathrm{M}$. Sc.(Agri.) Thesis. 1994, Dharwad.

8. Rajkumar K. Study on the effect of nutrient management on yield and quality of maize. M. Sc.(Ag.) Thesis 2011. Annamalai university, Annamalainagar

9. Singh RK, Athokpam HS, Changteand Z, Singh NG. Integrated management of Azolla, vermicompost and urea on yield of and nutrient uptake by rice and soil fertility. Journal of the Indian Society of Soil Science. 2005;53:107-10.

10. Bandyopadhyay BK, Bandyopadhyay AK, Bhargava GP. Characterization of Soil Potassium and Quantity/Intensity Relationship of Potassium in Some Coastal Soils. Journal of the Indian Society of Soil Science. 1985;33:548-54. 